\title{
Correction to: Can a Good Person be a Good Trader? An Ethical Defense of Financial Trading
}

\author{
Marta Rocchi ${ }^{1}$ (1) David Thunder ${ }^{2}$ (I)
}

Published online: 4 January 2021

(c) The Author(s) 2020

\section{Correction to: Journal of Business Ethics (2019) 159:89-103 https://doi.org/10.1007/s10551-017-3756-3}

The article Can a Good Person be a Good Trader? An Ethical Defense of Financial Trading, written by Marta Rocchi and David Thunder, was originally published Online First without Open Access. After publication in volume 159, issue 1, page 89-103 the authors decided to opt for Open Choice and to make the article an Open Access publication. Therefore, the copyright of the article has been changed to (C) The Authors 2017 and the article is forthwith distributed under the terms of the Creative Commons Attribution 4.0 International License (http://creativecommons.org/licenses/ by/4.0/), which permits unrestricted use, distribution, and reproduction in any medium, provided you give appropriate credit to the original author(s) and the source, provide a link to the Creative Commons license, and indicate if changes were made.

Open Access This article is licensed under a Creative Commons Attribution 4.0 International License, which permits use, sharing, adaptation, distribution and reproduction in any medium or format, as long as you give appropriate credit to the original author(s) and the source, provide a link to the Creative Commons licence, and indicate if changes were made. The images or other third party material in this article are included in the article's Creative Commons licence, unless indicated otherwise in a credit line to the material. If material is not included in the article's Creative Commons licence and your intended use is not permitted by statutory regulation or exceeds the permitted use, you will need to obtain permission directly from the copyright holder. To view a copy of this licence, visit http://creativecommons.org/licenses/by/4.0/.

Publisher's Note Springer Nature remains neutral with regard to jurisdictional claims in published maps and institutional affiliations.
The original article can be found online at https://doi.org/10.1007/ s10551-017-3756-3.

\section{Marta Rocchi}

mrocchi@pusc.it

David Thunder

dthunder@unav.es

1 Markets, Culture and Ethics Research Centre, Pontifcia Università della Santa Croce, via dei Farnesi, 83, 00186 Rome, Italy

2 Institute for Culture and Society - Religion and Civil Society Project, Universidad de Navarra, Campus Universitario, 31009 Pamplona, Navarra, Spain 